A $\mathrm{C}$ publications $R e c$. Nat. Prod. 13:2(2019) 172-175

records of natural products

\title{
Chemical Constituents of Essential Oils Extracted from the Leaves and Flowers of Spiranthera odoratissima A. St. Hil. (Rutaceae)
}

\author{
Fernando Duarte Cabral ${ }^{\oplus 1}$, Cassia Cristina Fernandes Alves ${ }^{\oplus 1}$, Rodrigo \\ Sebastião Cruvinel Cabral $^{\oplus 1}$, Guilherme Brinker Willrich ${ }^{\circledR 2}$, \\ Antônio Eduardo Miller Crotti ${ }^{\oplus 2}$ and Mayker Lazaro Dantas Miranda ${ }^{\oplus *}$ \\ ${ }^{1}$ Instituto Federal de Educação, Ciência e Tecnologia Goiano, Campus Rio Verde, Rio Verde, GO, \\ Brazil \\ ${ }^{2}$ Departamento de Química, Faculdade de Filosofia, Ciências e Letras de Ribeirão Preto, Ribeirão \\ Preto, SP, Brazil \\ ${ }^{3}$ Instituto Federal de Educação, Ciência e Tecnologia do Triângulo Mineiro, Campus \\ Uberlândia Centro, Uberlândia, $M G$, Brazil
}

(Received July 8, 2018; Revised September 5, 2018; Accepted September 11, 2018)

\begin{abstract}
Spiranthera odoratissima A. St. Hil. (Rutaceae), a plant grown in midwestern Brazil, has been used for treating rheumatism, infection and abdominal pain. This research aims to investigate chemical constituents of essential oils from $S$. odoratissima A. St. Hil. leaves and flowers. Essential oils were obtained by hydrodistillation and fully characterized by gas chromatography-flame ionization detection (GC-FID) and gas chromatographymass spectrometry (GC-MS). Results of the essential oil from S. odoratissima A. St. Hil. leaves showed that it has 28 volatile compounds which represent $93.8 \%$ of the oil. Its major compounds were $\beta$-caryophyllene $(23.8 \%)$, bicyclogermacrene $(10.8 \%), \delta$-cadinene $(7.1 \%)$, germacrene D $(5.9 \%), \alpha$-copaene $(5.5 \%)$ and $\beta$-elemene $(5.3 \%)$. Results of the essential oil from $S$. odoratissima A. St. Hil. flowers showed that it has 29 volatile compounds which represent $94.4 \%$ of the oil. Its main constituents were $\beta$-caryophyllene $(14.1 \%)$, spathulenol $(8.1 \%), \gamma$ cadinene $(7.2 \%), \alpha$-cadinol $(6.6 \%), \alpha$-copaene $(6.4 \%), \tau$-muurolol $(6.3 \%)$, $\delta$-cadinene $(5.8 \%), \beta$-elemene $(5.4 \%)$ and alloaromadendrene (5.2\%). In this research, chemical constituents of the essential oil from S. odoratissima A. St. Hil. flowers were investigated for the first time.
\end{abstract}

Keywords: Spiranthera odoratissima A. St. Hil.; Rutaceae; essential oils; $\beta$-caryophyllene; medicinal plant. (C) 2018 ACG Publications. All rights reserved.

\footnotetext{
* Corresponding author: E-Mail:maykermiranda@iftm.edu.br (Mayker Miranda); Phone: +34-32292538
} 


\section{Plant Source}

S. odoratissima A. St. Hil. leaves and flowers (S16 24'11.2''S and $51^{\circ} 06^{\prime} 41.4^{\prime \prime} \mathrm{W}$ ) were collected in November 2017 in Iporá, GO, Brazil. The plant was identified by the botanist Erika Amaral, M. Sc., and a voucher specimen (\#1039) was deposited in the herbarium in Rio Verde, at the Instituto Federal Goiano (IFGOIANO).

\section{Previous Studies}

The genus Spiranthera (Rutaceae) comprises three species distributed in South America, mainly in Brazil, Bolivia, Guyana and Venezuela [1]. Regarding its chemical composition, the species $S$. odoratissima contains furoquinoline and $\beta$-indoloquinazoline alkaloids, coumarin, terpene, steroid and limonoids [2]. S. odoratissima A. St. Hillaire, which is a shrub found in the Brazilian Cerrado, has been known in Brazil as manacá [3]. In folk medicine, its leaves and roots have been widely used for treating various diseases, such as syphilis, rheumatism, renal infections, urinary retention, abdominal pain, gout, furuncles and acne [4]. Anti-inflammatory, analgesic, anxiolytic and antiprotozoal activities of essential oils from S. odoratissima A. St. Hil. have been reported in the literature [4].

In this research, chemical constituents of essential oils from S. odoratissima A. St. Hil. leaves and flowers collected in Iporá, GO, Brazil, were identified. This is the first time that the analysis of chemical constituents of essential oils from S. odoratissima A. St. Hil. flowers has been conducted.

\section{Present Study}

S. odoratissima A. St. Hil. leaves and flowers were subjected to hydrodistillation for 2 hours by a Clevenger-type apparatus. In order to carry out the analysis, $300 \mathrm{~g}$ plant material was divided into three 100-g samples and $500 \mathrm{~mL}$ distilled water was added to each sample. After manual collection of essential oil samples, traces of remaining water in the oils were removed with anhydrous sodium sulfate, which was followed by filtration. The extraction procedure was done in triplicate. The isolated oil was stored under refrigeration up to the analysis and test. Yields $(\mathrm{w} / \mathrm{w})$ were calculated from fresh leaf and flower weight and expressed as the average of the triplicate analyses.

Gas chromatography (GC) analyses were performed by a Shimadzu GC2010 plus gas chromatograph equipped with an AOC-20s autosampler and fitted with fitted with flame ionization detector (FID) and a data-handling processor. An Rtx-5 (Restek Co., Bellefonte, PA, USA) fused silica capillary column (30-m x $0.25-\mathrm{mm}$ i.d.; $0.25-\mu \mathrm{m}$ film thickness) was employed. Operation conditions were as follows: column temperature programmed to rise from 60 to $240{ }^{\circ} \mathrm{C}$ at $3{ }^{\circ} \mathrm{C} / \mathrm{min}$ and then hold at $240{ }^{\circ} \mathrm{C}$ for $5 \mathrm{~min}$; carrier gas $=\mathrm{He}(99.999 \%)$, at $1.0 \mathrm{~mL} / \mathrm{min}$; injection mode; injection volume, 0.1 $\mu \mathrm{L}$ (split ratio of 1:10); and injector and detector temperatures $=240$ and $280{ }^{\circ} \mathrm{C}$, respectively. Relative concentrations of components were obtained by peak area normalization (\%). Relative areas were the average of triplicate GC-FID analyses.

GC-MS analyses were carried out by a Shimadzu QP2010 Plus (Shimadzu Corporation, Kyoto, Japan) system equipped with an AOC-20i autosampler. The column was an RTX-5MS (Restek Co., Bellefonte, PA, USA) fused silica capillary one $(30 \mathrm{~m} \times 0.25 \mathrm{~mm}$ i.d. $\times 0.25 \mu \mathrm{m}$ film thickness). Electron ionization mode occurred at $70 \mathrm{eV}$. Helium (99.999 \%) was employed as the carrier gas at a constant flow of $1.0 \mathrm{~mL} / \mathrm{min}$. The injection volume was $0.1 \mu \mathrm{L}$ (split ratio of $1: 10$ ). Injector and ionsource temperatures were set at 240 and $280{ }^{\circ} \mathrm{C}$, respectively. The oven temperature program was the same as the one used for GC. Mass spectra were taken at a scan interval of $0.5 \mathrm{~s}$, in the mass range from 40 to $600 \mathrm{Da}$. Identification of volatile components of S. odoratissima A. St. Hil. leaves and flowers (Table 1) was based on their retention indices on an RTX-5MS capillary column under the same operating conditions as the ones found in the case of GC, related to a homologous series of $n$-alkanes $\left(\mathrm{C}_{8}-\mathrm{C}_{20}\right)$. Structures were computer-matched with the Wiley 7, NIST 08 and FFNSC 1.2 spectra libraries and their fragmentation patterns were compared with literature data [5]. 
Table 1. Chemical constituents of essential oils from S. odoratissima A. St. Hil. leaves and flowers

\begin{tabular}{|c|c|c|c|c|}
\hline \multirow{2}{*}{ Compounds } & \multirow[b]{2}{*}{$\mathrm{RI}_{\text {exp }}$} & \multirow[b]{2}{*}{$\mathrm{RI}_{\text {lit }}$} & \multicolumn{2}{|c|}{$\% \mathrm{RA}$} \\
\hline & & & Leaves & Flowers \\
\hline limonene & 1030 & 1031 & 0.5 & 0.5 \\
\hline linalool & 1101 & 1098 & - & 1.0 \\
\hline terpinen-4-ol & 1171 & 1177 & - & 0.3 \\
\hline$\alpha$-terpineol & 1190 & 1192 & - & 0.4 \\
\hline bicycloelemene & 1327 & 1331 & 1.3 & 0.3 \\
\hline$\alpha$-cubebene & 1358 & 1352 & 2.3 & 2.1 \\
\hline$\alpha$-copaene & 1365 & 1372 & 5.5 & 6.4 \\
\hline$\beta$-elemene & 1389 & 1392 & 5.3 & 5.4 \\
\hline$\beta$-caryophyllene & 1416 & 1418 & 23.8 & 14.1 \\
\hline$\alpha$-bergamotene & 1430 & 1436 & 0.6 & 1.6 \\
\hline$\alpha$-humulene & 1447 & 1455 & 4.8 & 3.9 \\
\hline alloaromadendrene & 1455 & 1461 & 2.6 & 5.2 \\
\hline$\gamma$-muurolene & 1472 & 1477 & 1.1 & 1.9 \\
\hline germacrene D & 1478 & 1480 & 5.9 & 3.3 \\
\hline$\beta$-selinene & 1482 & 1485 & 1.5 & 0.9 \\
\hline bicyclogermacrene & 1490 & 1496 & 10.8 & 4.2 \\
\hline$\alpha$-muurolene & 1494 & 1499 & - & 2.7 \\
\hline germacrene A & 1501 & 1503 & 0.4 & 0.4 \\
\hline$\gamma$-cadinene & 1510 & 1513 & 3.0 & 7.2 \\
\hline$\delta$-cadinene & 1521 & 1524 & 7.1 & 5.8 \\
\hline$\alpha$-cadinene & 1533 & 1538 & 0.3 & 0.7 \\
\hline germacrene B & 1554 & 1561 & 0.5 & - \\
\hline spathulenol & 1581 & 1578 & 2.9 & 8.1 \\
\hline caryophyllene oxide & 1585 & 1583 & 1.6 & 3.0 \\
\hline viridiflorol & 1591 & 1595 & 1.2 & 0.7 \\
\hline epiglobulol & 1601 & 1598 & - & 0.4 \\
\hline carotol & 1613 & 1597 & 0.3 & - \\
\hline humulane-1.6-dien-3-ol & 1618 & 1619 & 0.3 & - \\
\hline isoaromadendrene epoxide & 1623 & 1622 & 0.5 & 0.4 \\
\hline$\tau$-muurolol & 1643 & 1640 & 4.3 & 6.3 \\
\hline$\delta$-cadinol & 1647 & 1645 & 0.5 & 0.6 \\
\hline$\alpha$-cadinol & 1658 & 1653 & 4.7 & 6.6 \\
\hline nootkatone & 1810 & 1807 & 0.2 & - \\
\hline Monoterpene hydrocarbons & & & 0.5 & 0.5 \\
\hline Oxygenated monoterpenes & & & - & 1.7 \\
\hline Sesquiterpene hydrocarbons & & & 76.6 & 66.1 \\
\hline Oxygenated sesquiterpenes & & & 16.7 & 26.1 \\
\hline Total & & & 93.8 & 94.4 \\
\hline
\end{tabular}

$\mathrm{RI}_{\text {exp }}$ : Retention index relative to $n$-alkanes $\left(\mathrm{C}_{8}-\mathrm{C}_{20}\right)$ in the Rtx-5MS column; $\mathrm{RI}_{\text {lit }}$ : Retention index found in the literature [5]. RA\%: relative area. 
Twenty-eight components were identified in oils from S. odoratissima A. St. Hil. leaves, which exhibited about $93.8 \%$ of the total composition of the oil, whereas twenty-nine components were identified in oils from its flowers, which showed about $94.4 \%$ of the total composition of the oil. Major constituents of essential oils from its flowers were $\beta$-caryophyllene (14.1\%), spathulenol $(8.1 \%), \gamma$ cadinene $(7.2 \%), \alpha$-cadinol $(6.6 \%), \alpha$-copaene $(6.4 \%), \tau$-muurolol $(6.3 \%), \delta$-cadinene $(5.8 \%), \beta$ elemene (5.4\%) and alloaromadendrene (5.2\%). Major constituents of essential oils from its leaves were $\beta$-caryophyllene $(23.8 \%)$, bicyclogermacrene $(10.8 \%), \delta$-cadinene $(7.1 \%)$, germacrene D $(5.9 \%), \alpha$ copaene $(5.5 \%)$ and $\beta$-elemene (5.3\%). The chemical composition of essential oils from S. odoratissima A. St. Hil. leaves was similar to the one previously described in the literature [4]. This research on essential oils from $S$. odoratissima A. St. Hil. adds relevant chemotaxonomic information to the literature, since there have been reports of the isolation of furoquinoline and $\beta$-indoloquinazoline alkaloids, coumarin, terpene, steroid and limonoids of this species [6]. Chemical constituents of oils from S. odoratissima A. St. Hil. are described in Table 1. The second step will be to evaluate biological activities of these essential oils in order to value this species with a special ecological character.

\section{Acknowledgments}

The authors would like to thank FAPEG, CNPq, IFGOIANO - Campus Rio Verde and CAPES for their financial support.

\section{ORCID}

Fernando Duarte Cabral: 0000-0002-5090-5946

Cassia Cristina Fernandes Alves: 0000-0003-2004-3166

Rodrigo Sebastião Cruvinel Cabral: 0000-0001-8436-0529

Guilherme Brinker Willrich: 0000-0002-6820-8356

Antônio Eduardo Miller Crotti: 0000-0001-6047-4871

Mayker Lazaro Dantas Miranda: 0000-0003-4689-572X

\section{References}

[1] J. R. Pirani (2010). Spiranthera atlantica (Rutaceae, Galipeae), a new species and the first record of the genus for the Brazilian Atlantic Forest, Novon 20(2), 203-206.

[2] A. P. Terezan, R. A. Rossi, R. N. A. Almeida, T. G. Freitas, J. B. Fernandes, M. F. G. F. Silva, P. C. Vieira, O. C. Bueno, F. C. Pagnocca, and J. R. Pirani (2010). Activities of extract and compounds from Spiranthera odoratissima St. Hil. (Rutaceae) in leaf-cutting ants and their symbiotic fungus, J. Braz. Chem. Soc. 21(5), 882-886.

[3] L. G. Matos, I. S. Pontes, L. M. F. Tresvenzol, J. R. Paula, and E. A. Costa (2004). Analgesic and antiinflammatory activity of the ethanolic extract from Spiranthera odoratissima A. St. Hillaire (Manacá) roots, Phytother. Res. 18(12), 963-966.

[4] S. J. O. Souza, P. H. Ferri, T. S. Fiuza, L. L. Borges, and J. R. Paula (2018). Chemical composition and seasonality variability of the Spiranthera odoratissima volatile oils leaves, Braz. J. Pharmacog. 28(1), 16-20.

[5] R.P. Adams (2007). Identification of essential oil components by gas chromatography/mass spectroscopy. Allured publishing Co. Carol Stream, Illinois.

[6] B. A. Chaibub, T. B. Oliveira, T. S. Fiuza, M. T. F. Bara, L. M. F. Tresvenzol and J. R. Paula (2013). Composição química do óleo essencial e avaliação da atividade antimicrobiana do óleo essencial, extrato etanólico bruto e frações das folhas de Spiranthera odoratissima A. St.-Hil., Rev. Bras. Pl. Med. 15(2), 225-229.

$$
\underset{\substack{\text { publications } \\ \text { (c) 2018 ACG Publications }}}{\text { A }}
$$

